\title{
PICUS SONIC TOMOGRAPHY FOR THE QUANTIFICATION OF DECAY IN WHITE OAK (QUERCUS ALBA) AND HICKORY (CARYA SPP.)
}

\author{
by Elizabeth A. Gilbert ${ }^{1}$ and E. Thomas Smiley ${ }^{2}$
}

\begin{abstract}
The Picus Sonic Tomograph is a noninvasive tool for assessing decay in trees. It works on the principle that sound waves passing through decay move more slowly than sound waves transversing solid wood. By sending sound waves from a number of points around a tree trunk to the same number of receiving points, the relative speed of the sound can be calculated, and a two-dimensional image of the cross-section of the tree, a tomogram, can be generated. Picus tomography and visual inspection were used to evaluate 27 cross-sections from 13 trees. The tomograms correlated closely with the visual assessment of decay. In 10 samples where no decay was present, Picus found no decay. In the remaining 17 samples, Picus detected less decay than was observed visually. Differences in most cases were small (average of $5 \%$ of total area). In terms of predicting the location of decay, on average $3 \%$ of the total area was a false positive (where the tomogram showed that decay was present but the crosssection did not), and an average of $8 \%$ of the area was false negative (the cross-section showed decay that was not seen on the tomogram).
\end{abstract}

Key Words. Hazard trees; tree risk analysis; tree failure

A number of products and techniques are now marketed for detecting and assessing decay in trees, reviews of which can be found in the literature (Mattheck and Breloer 1994;

Nicoletti and Miglietta 1998; Harris et al. 1999; Lonsdale 1999). Equipment and techniques such as the Resistograph®, drilling, and the increment borer involve drilling through the bark into the xylem (Smiley and Fraedrich 1992; Costello and Quarles 1999). There may be some disadvantages associated with drilling (Harris et al. 1999). The Picus Sonic Tomograph (Argus Electronics GmbH, Rostock, Germany) was developed as a noninvasive method to quantify and locate wood decay.

Sonic tomography is a technique used to produce an image of the internal structure of a solid object by recording differences in the speed of sound wave transmission. The Picus Sonic Tomograph consists of a set of sensors (typically 8 to 12$)$ that are connected to the trunk by pins (roofing nails) 0.8 to $2 \mathrm{~mm}$ (0.03 to 0.7 in.) in diameter (Figure 1). Sound waves are produced by tapping each sensor with a small hammer. The Picus system measures the transmission time from each impact with the hammer to each sensor. By measuring the distances between sensors, apparent sound velocities are calculated by the system software, from which wood density is determined. Using these data, a two-dimensional image, or tomogram, of the tree cross-section is generated.

This research project was undertaken to determine whether the Picus Sonic Tomograph can detect decay and to determine the correlation between tomograms and the amount and location of actual decay in trees.

\section{MATERIALS AND METHODS}

A Picus Sonic Tomograph was provided by Argus Electronics GmbH, Rostock, Germany. Trees were located at the Bartlett Tree Research Laboratory in Charlotte, North Carolina, U.S. Tomograph measurements were taken on 27 cross-sections from 13 trees thought to have decay. Eight to 10 sensor pins were equally spaced around the trunk and driven into the sapwood in a horizontal plane according to the manufacturer's instructions. A sensor was magnetically attached to each pin and tapped three times with a steel hammer. A tomogram was created for each cross-section. All the tomograms were calculated using the July 2002 Picus software release.

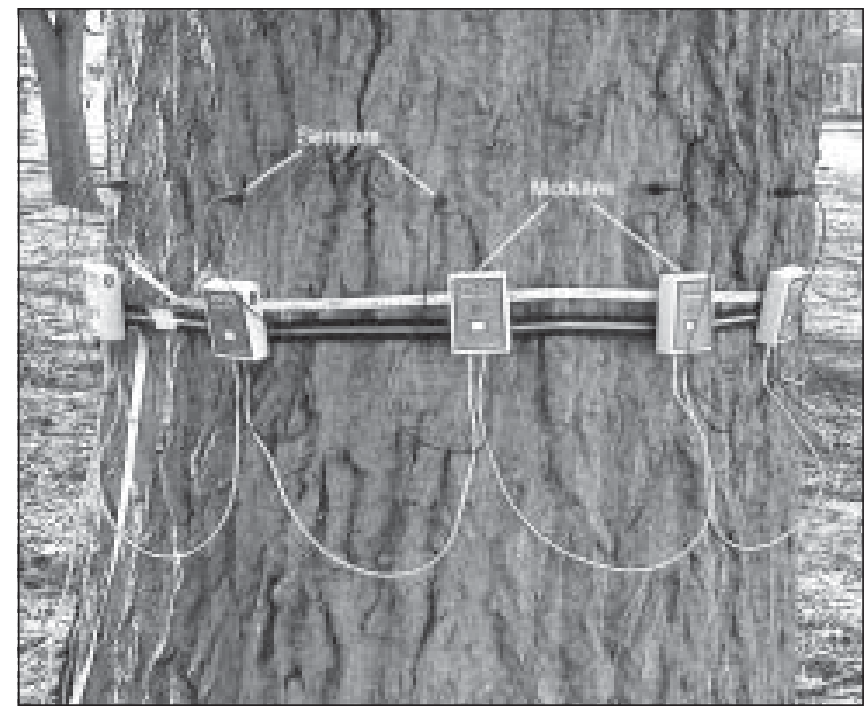

Figure 1. Picus setup showing sensors and modules. 
The trees were felled with the numbered pins left in place. Sections were cut at a distance of about $2.5 \mathrm{~cm}$ ( 1 in.) either side of the sensor pin plane. The circumference of each section was measured and an average diameter calculated by dividing the circumference by $\pi$. Crosssections were photographed using a digital camera. Measurements were taken between sensor pins, using a tape measure, so that the "Free Geometry" option in the Picus software could be used to generate the tomogram. The photos and tomograms were scaled using Adobe Photoshop® and printed one image to one sheet.

A grid with $5 \mathrm{~mm}$ (0.02 in.) squares was printed onto a sheet of clear plastic (transparency). Each square was marked as either decayed or not decayed for both the crosssection photograph and the tomogram. Areas considered decayed on the tomogram appeared as pink or blue (areas that appeared green in the tomogram are transition areas between sound wood and decay and were not considered decayed). The area containing decay was determined for each photographic cross-section. In areas of the photographs where decay was not clearly defined, the actual trunk cross-section was visually examined to clarify whether decay was present. Decay was defined as the absence of wood or wood soft enough to be deflected with finger pressure. If a square contained both decayed and sound wood, it was considered decayed. These measurements were used to evaluate both the area of decay and the location of decay. Area of decay was calculated as a percentage of squares identified as decayed divided by the total area of wood. For the tomograms, the area of decay was calculated by the Picus software. The correlation between the amount of decay indicated by Picus and that identified by visual evaluation was calculated.

Accuracy of the Picus's ability to locate decay was determined by comparing the actual location of decay in the photographic cross-sections with their tomograms. Grid squares where the tomogram showed decay and the photograph showed no decay (false positives) were counted, as were the grid squares where the photo showed decay and the tomogram did not (false negatives). Area of the squares was recorded as a percentage of the total area of the cross-section. Accuracy was calculated by dividing the area of false positives plus the area of false negatives by the total cross-sectional area.

\section{RESULTS}

Of the 27 cross-sections measured, 17 were found to have some decay and 10 were found to have none. In all cases where no decay was visually evident, the same result was reflected in the tomogram.

\section{Area of Decay}

There was a high correlation between the amount of decay detected by the Picus and the amount actually present in the cross-sections $\left(r^{2}=0.94\right)$ for all cross-sections. For cross-sections where decay was present, the correlation coefficient is $r^{2}=0.90$

In 14 of 17 cross-sections, Picus calculated slightly less decay than was visually apparent (Table 1 ). The average discrepancy between the percentages of decay found in these cases was 6\% (standard deviation 5.0\%). In three cases where Picus calculated decay to be greater than that measured by visual evaluation, the average discrepancy was $1 \%$ (standard deviation $1.1 \%$ ).

\section{Location of Decay}

In samples where decay was present, on average $2 \%$ of the total area of the sample was false positive where the tomogram showed that decay was present but the crosssection did not. False negatives (where the cross-section showed decay that was not seen on the tomogram) were present on average in $9 \%$ of the readings (Table 1). The average percentage accuracy for samples where decay was present was $89 \%$.

\section{DISCUSSION}

The Picus Sonic Tomograph did an excellent job of identifying tree cross-sections containing decay. If any significant decay was present in a section, Picus was able to detect it.

In cross-sections with decay, Picus did a very good job of determining the area of decay and location of the decay. Results show that, on average, Picus shows less decay in the samples than is found by visual inspection, although the amount by which the two figures differ, in most cases, is small.

As with any drilling method to assess decay, the depth to decay is determined at only a few locations around the stem; therefore, if the pattern of decay is irregular, the level of accuracy will rapidly drop. Compared to other methods of decay detection that require drilling, Picus gives an image across the whole cross-section.

The "Free Shapes" option in the Picus software, for measurement of tree geometry, was used for all samples in this study because it was found to calculate the most accurate tomogram. Using this option, the distance between all sensors is measured. The alternative is to make the assumption that the cross-section is either circular (which requires measurement of the circumference) or elliptical (where measurement of the diameter at the widest and narrowest planes is required). Most cross-sections were irregular in shape. In this study, the distance between sensors was measured after the Picus data had been collected and the cross-section of the trunk had been cut. In the field, this procedure is would be done with a set of large calipers in the standing tree. Argus Electronics is currently developing a large electronic caliper. The data measured with this device will be sent directly to the Picus program. 
Table 1. Area and location of decay determined by Picus or visual examination and a comparison of the two measurements on all trees in the study.

\begin{tabular}{|c|c|c|c|c|c|c|c|c|c|c|}
\hline \multirow[b]{2}{*}{ Species } & \multirow[b]{2}{*}{ ID } & \multirow[b]{2}{*}{ Section } & \multirow{2}{*}{$\begin{array}{l}\text { No. of } \\
\text { Picus } \\
\text { sensors }\end{array}$} & \multirow{2}{*}{$\begin{array}{l}\text { Average } \\
\text { diameter } \\
(\mathrm{cm})\end{array}$} & \multicolumn{2}{|c|}{ Percentage decay } & \multirow[b]{2}{*}{ Difference } & \multicolumn{2}{|c|}{$\begin{array}{c}\text { Percentage of } \\
\text { total area }\end{array}$} & \multirow[b]{2}{*}{$\begin{array}{l}\text { Percentage } \\
\text { accuracy }^{x}\end{array}$} \\
\hline & & & & & $\begin{array}{l}\text { Picus } \\
\text { evaluation }\end{array}$ & $\begin{array}{l}\text { Visual } \\
\text { evaluation }\end{array}$ & & $\begin{array}{l}\text { False } \\
\text { positives }^{z}\end{array}$ & $\begin{array}{l}\text { False } \\
\text { negatives }^{y}\end{array}$ & \\
\hline White oak & 1 & Bottom & 10 & 48 & $23 \%$ & $28 \%$ & $5 \%$ & $5 \%$ & $10 \%$ & $85 \%$ \\
\hline White oak & 1 & Middle & 10 & 42 & $0 \%$ & $0 \%$ & $0 \%$ & $0 \%$ & $0 \%$ & $100 \%$ \\
\hline White oak & 1 & Top & 10 & 40 & $0 \%$ & $0 \%$ & $0 \%$ & $0 \%$ & $0 \%$ & $100 \%$ \\
\hline White oak & 2 & Bottom & 10 & 36 & $36 \%$ & $35 \%$ & $-1 \%$ & $11 \%$ & $9 \%$ & $79 \%$ \\
\hline White oak & 2 & Top & 10 & 27 & $0 \%$ & $0 \%$ & $0 \%$ & $0 \%$ & $0 \%$ & $100 \%$ \\
\hline White oak & 3 & Bottom & 10 & 49 & $9 \%$ & $12 \%$ & $3 \%$ & $1 \%$ & $4 \%$ & $95 \%$ \\
\hline White oak & 3 & Top & 10 & 44 & $0 \%$ & $0 \%$ & $0 \%$ & $0 \%$ & $0 \%$ & $100 \%$ \\
\hline White oak & 4 & Bottom & 10 & 46 & $0 \%$ & $0 \%$ & $0 \%$ & $0 \%$ & $0 \%$ & $100 \%$ \\
\hline White oak & 4 & Top & 10 & 38 & $0 \%$ & $0 \%$ & $0 \%$ & $0 \%$ & $0 \%$ & $100 \%$ \\
\hline White oak & 5 & Bottom & 10 & 28 & $0 \%$ & $0 \%$ & $0 \%$ & $0 \%$ & $0 \%$ & $100 \%$ \\
\hline White oak & 5 & Top & 10 & 25 & $0 \%$ & $0 \%$ & $0 \%$ & $0 \%$ & $0 \%$ & $100 \%$ \\
\hline White oak & 6 & Bottom & 10 & 41 & $10 \%$ & $12 \%$ & $2 \%$ & $3 \%$ & $4 \%$ & $93 \%$ \\
\hline White oak & 7 & Bottom & 10 & 36 & $3 \%$ & $0 \%$ & $-3 \%$ & $3 \%$ & $0 \%$ & $97 \%$ \\
\hline White oak & 7 & Top & 10 & 27 & $0 \%$ & $0 \%$ & $0 \%$ & $0 \%$ & $0 \%$ & $100 \%$ \\
\hline White oak & 8 & Bottom & 10 & 35 & $26 \%$ & $35 \%$ & $9 \%$ & $3 \%$ & $15 \%$ & $82 \%$ \\
\hline White oak & 9 & Bottom & 10 & 49 & $16 \%$ & $36 \%$ & $20 \%$ & $2 \%$ & $21 \%$ & $77 \%$ \\
\hline White oak & 9 & Top & 10 & 37 & $26 \%$ & $28 \%$ & $2 \%$ & $4 \%$ & $5 \%$ & $91 \%$ \\
\hline Hickory spp. & 10 & Bottom & 10 & 40 & $7 \%$ & $16 \%$ & $9 \%$ & $2 \%$ & $9 \%$ & $89 \%$ \\
\hline Hickory spp. & 10 & Middle & 9 & 33 & $0 \%$ & $1 \%$ & $1 \%$ & $0 \%$ & $1 \%$ & $99 \%$ \\
\hline Hickory spp. & 10 & Top & 9 & 29 & $0 \%$ & $0 \%$ & $0 \%$ & $0 \%$ & $0 \%$ & $100 \%$ \\
\hline Hickory spp. & 11 & Bottom & 10 & 36 & $2 \%$ & $14 \%$ & $12 \%$ & $0 \%$ & $10 \%$ & $90 \%$ \\
\hline Hickory spp. & 11 & Middle & 8 & 31 & $4 \%$ & $12 \%$ & $8 \%$ & $2 \%$ & $7 \%$ & $92 \%$ \\
\hline Hickory spp. & 11 & Top & 8 & 31 & $9 \%$ & $10 \%$ & $1 \%$ & $2 \%$ & $3 \%$ & $95 \%$ \\
\hline Hickory spp. & 12 & Bottom & 8 & 32 & $30 \%$ & $30 \%$ & $0 \%$ & $5 \%$ & $2 \%$ & $93 \%$ \\
\hline Hickory spp. & 12 & Middle & 8 & 27 & $18 \%$ & $23 \%$ & $5 \%$ & $4 \%$ & $9 \%$ & $87 \%$ \\
\hline Hickory spp. & 12 & Top & 8 & 27 & $17 \%$ & $24 \%$ & $7 \%$ & $2 \%$ & $12 \%$ & $86 \%$ \\
\hline White oak & 13 & Bottom & 8 & 30 & $37 \%$ & $45 \%$ & $8 \%$ & $5 \%$ & $14 \%$ & $80 \%$ \\
\hline
\end{tabular}

${ }^{2}$ False positive area was where Picus detected decay, but none was present.

${ }^{y}$ False negative area was where Picus did not detect decay, but decay was present.

xAccuracy was calculated by dividing the area where both Picus and the visual examination of photographs showed decay by the total cross-sectional area.

Tomogram quality near the bark appeared to be lower than in other portions for the cross-section. The decreased quality is probably due to a lack of straight-line sound transmissions in this curved area. Improvement of the handling of the edges would be beneficial because this is a critical area in terms of the stability of the tree.

Borer holes approximately $1 \mathrm{~cm}(0.4 \mathrm{in}$.) diameter were apparent in certain cross-sections (e.g., white oak 8, Figure 2 ), but they were not revealed in the tomogram. These holes are not of a size that would affect the stability of the trunk. The lower limit to the size of defect that the Picus can detect depends on the size of the tree, number of sensors, and type of wood. The higher the density of the wood, the smaller the defect that can be detected. In general, the smallest detectable defect is in the range of 5 to $10 \mathrm{~cm}$ (2 to $4 \mathrm{in}$.) (Lothar Göcke, personal communication).

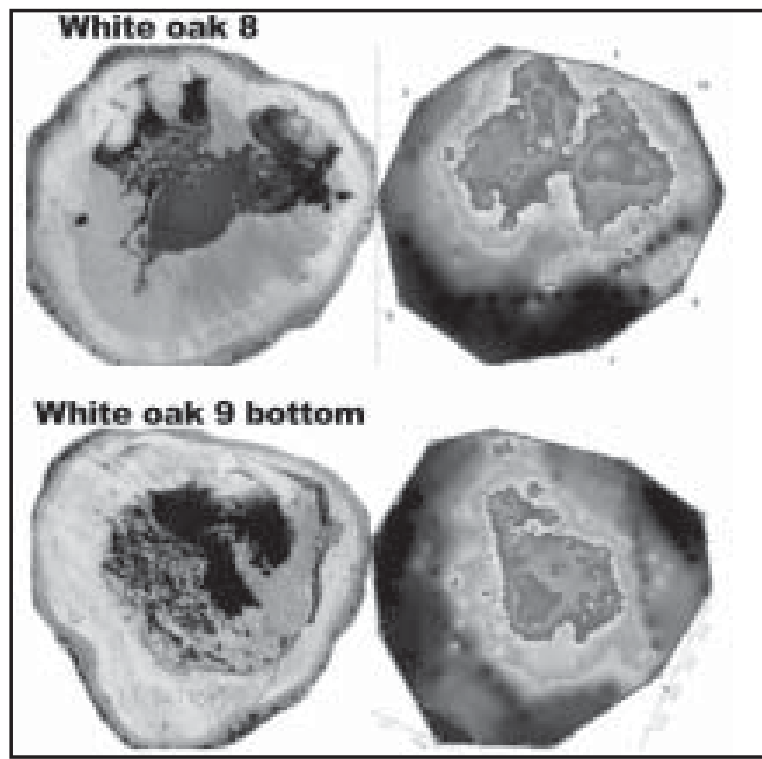

Figure 2. Photographs and tomograms of selected trunk cross-sections used in this study. 


\section{LITERATURE CITED}

Costello, L.R., and S.L. Quarles. 1999. Detection of wood decay in blue gum and elm: An evaluation of the Resistograph and the portable drill. J. Arboric. 25(6): 311-317.

Harris, R.W., J.R. Clark, and N.P. Matheny. 1999. Arboriculture: Integrated Management of Landscape Trees, Shrubs, and Vines. Prentice Hall, Englewood Cliffs, NJ. 687 pp.

Lonsdale, D. 1999. Principles of tree hazard assessment and management. Department of the Environment, Transport and the Regions, London, UK. 388 pp.

Mattheck, C.G., and K.A. Bethge. 1993. Detection of decay in trees with the Metriguard stress wave timer. J. Arboric. 19(6):374-378.

Mattheck, C., and H. Breloer. 1994. The Body Language of Trees. The Stationary Office, Norwich, UK. 239 pp.

Nicoletti, G., and P. Miglietta. 1998. Using high-technology instruments to detect decay in trees. J. Arboric. 24(6): 297-302.

Smiley, E.T. 1998. Countersinking for tree bolts. J. Arboric. 24(5):245-246.

Smiley, E.T., and B.R. Fraedrich. 1992. Determining strength loss from decay. J. Arboric. 18(4):201-204.
Acknowledgments. We would like to acknowledge the following people who have contributed to this research project: Lothar Göcke of Argus Electronics (www.argus-electronic.de) and Steffen Rust of the Institute of Forest Botany and Forest Zoology, Technical University of Dresden, Dresden, Germany, for technical assistance with the Picus; Elden LeBrun for technical support; James G. Williams, a statistician with the Department of Forestry, retired, Clemson University, Clemson, South Carolina; and Bruce Fraedrich, director of the Bartlett Tree Research Laboratories for his assistance and support.

${ }^{1}$ Capital Tree Relocators

Austin, TX, U.S.

$2^{2 *}$ Arboricultural Researcher

Bartlett Tree Research Laboratory

13768 Hamilton Road

Charlotte, NC 28278, U.S.

and

Adjunct Professor

Clemson University

Clemson, SC, U.S.

*Corresponding author. 
Résumé. Le tomographe sonique Picus est un outil non invasif pour évaluer le taux de carie dans les arbres. Il fonctionne sur le principe que les ondes sonores qui passent au travers du bois carié voyagent plus lentement que celles qui traversent du bois sain. En envoyant des ondes sonores de plusieurs endroits différents autour du tronc, et ce à un nombre équivalent de points de réception, la vitesse relative du son peut être calculée et une image bidimensionnelle d'une section transversale du tronc, soit un tomogramme, peut être obtenue. Le Picus et une inspection visuelle ont été employés afin d'évaluer 27 sections transversales de 13 arbres. Les tomogrammes se corrélaient intimement avec l'évaluation visuelle de la carie. Dans 10 échantillons où il y avait absence de carie, le Picus n'a détecté aucune zone de carie. Dans les 17 échantillons restants, le Picus a détecté moins de carie que ce qui était observé visuellement. Les différences dans la plupart des cas étaient faibles (moyenne de $5 \%$ de la superficie totale). En terme de prédiction de la localisation de la zone de carie, une moyenne de 3\% de la superficie totale était faussement positive (là où le tomogramme indiquait qu'il y avait de la carie mais où on n'en observait aucune dans la coupe transversale), et une moyenne de 8\% de la superficie totale était faussement négative (la section transversale montrait la présence de carie alors que le tomogramme ne la détectait pas).

Zusammenfassung. Der Picus-Schalltomograf ist ein nicht-invasives Werkzeug, um Fäule in Bäumen zu messen. Es arbeitet mit dem Prinzip, dass Schallwellen durch faules Holz langsamer laufen als durch intaktes Holz. Die verhältnismäßige Geschwindigkeit des Klanges kann berechnet werden, indem man Schallwellen um einen Baumstamm von einer Anzahl definierter Punkte zu einer gleichen Anzahl empfangender Punkte schickt und dadurch ein zweidimensionales Bild vom Querschnitt des Baumes, ein Tomogramm, erzeugt. Der Picus und visuelle Inspektionen wurden benutzt, um 27 Querschnitte von 13 Bäumen einzuschätzen. Die Tomogramme stimmten weitgehend mit der visuellen Inspektion überein. In 10 Proben ohne Befall fand der Tomograf auch keinen Befall. In den anderen 17 Proben identifizierte der Picus einen geringeren Fäulegrad als visuell identifiziert. Die Unterschiede waren in den meisten Fällen gering (5\% der totalen Fläche). In Bezug auf die Vorhersage der Fäulestellen waren im Durchschnitt bei $3 \%$ der totalen Fläche die positiven Aussagen fehlerhaft ( das Tomogramm zeigte Fäule, der Querschnitt aber nicht) und bei $8 \%$ gab es eine negative falsche Aussage ( der Querschnitt zeigte Fäule, aber der Tomograf nicht).

Resumen. El tomógrafo sónico Picus es una herramienta no invasora para evaluar la descomposición en los árboles. Trabaja con el principio de que las ondas sonoras pasan a través de la madera en descomposición más lentamente que en madera sana y sólida. Mediante el envío y recepción de ondas de sonido desde un número de puntos alrededor del tronco del árbol, se puede ser calcular la velocidad relativa del sonido y se genera una imagen de dos dimensiones de la sección transversal del árbol, un tomograma. El Picus y la inspección visual fueron usados para evaluar 27 secciones trasversales de 13 árboles. Los tomogramas correlacionaron estrechamente con la evaluación visual del decaimiento. En 10 muestras donde el decaimiento no estuvo presente, Picus no lo encontró. En las restantes 17 muestras Picus detectó menos decaimiento que las observaciones visuales. Las diferencias en la mayoría de los casos fueron pequeñas (un promedio del $5 \%$ del área total). En términos de predicción de la localización del decaimiento, en un promedio del 3\% del área total resultó falso positivo (donde el tomograma mostró que el decaimiento estuvo presente pero la sección trasversal no), y un promedio del 8\% del área fue falso negativo (la sección trasversal mostró decaimiento el cual no fue visto en el tomograma). 